\title{
実仕様による接着系アンカーを用いた $\mathrm{RC}$ 増設耐震壁の補強効果
}

\author{
益尾 潔 ${ }^{* 1} \cdot$ 杉本敏和 ${ }^{* 2} \cdot$ 小宮敏明 ${ }^{* 2} \cdot$ 太田実香 ${ }^{* 3}$
}

\begin{abstract}
概 要 本研究では, アンカー筋量を適切に考慮し得る $\mathrm{RC}$ 増設耐震壁の終局耐力評価法の開発を目的とし, 実仕様による接着系アンカーを用いた増設耐震壁について, アンカー筋量, 壁板コンクリート強度などが補強 効果に及ほす影響を実験的に明らかにした。 $\mathrm{RC}$ 増設耐震壁の終局耐力評価法に関しては, (1)終局曲げ耐力は, アンカー筋によって制限される壁縦筋の有効率を考慮することにより妥当に評価できる，(2)改修指針式による 終局せん断耐力は, アンカー筋量が少ないか, 既存架構よりも新設壁板コンクリート強度が高いと過小評価と なる，(3)改修指針式を修正した評価式により終局せん断耐力を適切に評価できることなどを示した。 キーワード : 増設耐震壁, 増打ち壁, 接着系アンカー, アンカー筋量, 壁板コンクリート強度, 終局耐力
\end{abstract}

1.はじめに

$\mathrm{RC}$ 増設耐震壁の工事では, アンカー施工時の騷音防 止等の観点より, アンカー量の低減が望まれる。一方， 耐震改修指針 ${ }^{11}$ による増設耐震壁の終局せん断耐力評価 式は, 種々の仕様による実験結果に対しても安全側にな るように設定されている2。同式の検証用の実験として は，ホールインアンカーを用いたもの $)^{8}$ るいは上梁下 端の隙間発生防止のための処理が施されていないもの ${ }^{5)}$ などが含まれている。そのため，同式によると，適切な 補強仕様によったとしても，アンカー筋で決まる終局せ ん断耐力が低く評価される恐れがある。

上記の背景より, 本研究では, 実仕様による接着系ア ンカーを用いた試験体について，下記の事項を明らかに することを目的として実験を行い，増設耐震壁の終局耐 力評価法について検討した。

1) (1)アンカー筋量, (2)新設壁板コンクリート強度, (3) 側柱の断面形状の 3 項目が増設耐震壁の終局耐力と変 形性状に及ほすす影響

2 ）増打ち壁の終局耐力と変形性状ならびに既存仕上げ モルタル残存の影響

\section{2. 実験計画}

\section{1 試験体概要}

試験体は, 標準的な学校校舎の桁行架構補強用の増設
耐震壁を想定し，縮小率を $1 / 2.5$ とした 1 層 1 スパンの 増設耐震壁である。試験体数は, 一体打ち壁試験体 W-0, 増設壁試験体 FW-1 FW-5 と増打ち壁試験体 FW-6, FW-7 の合計 8 体である。実験計画の一覧を表ー 1 に示 す。FW-1～FW-3はアンカー筋量の影響, FW-4 は側柱 の断面形状の影響, FW-5 は新設壁板コンクリート強度 の影響を調べるための試験体であり，FW-6，FW-7は増 打ち壁で，FW-7は既存仕上げモルタルが残存した試験 体である。

試験体の形状寸法, 配筋を図一1に示す。各試験体と も, 比較的剛強な上部梁を設け, 側柱の断面寸法は, 正 方形断面柱と長方形断面柱の断面積がほぼ等しくなるよ うにし，柱軸力比 $\mathrm{N} / \sigma_{\mathrm{B} 1 \mathrm{BD}}$ は 0.15 とした。ここに，B， Dは柱幅およびせい， $\sigma{ }_{\mathrm{B} 1}$ は既存コンクリートの実圧縮 強度であり, 表一 1 中の F $\mathrm{C}$ は設計基準強度を示す。

2.2 補強ディテール

(1)コンクリートの打設方法

既存架構, 増設壁板ともに, 縦打ちとした。

(2)アンカー筋

アンカー筋は接着系アンカーで, ピッチを 3 種類とし た。ただし，FW-6, FW-7は，増設壁試験体とアンカー 筋比が一致するように, 増打ち壁のアンカー筋のピッチ を決定した。

各試験体とも, アンカー筋の有効埋め込み深さ $\ell_{e}$ は $7 \mathrm{~d}_{\mathrm{a}}$ (耐震改修指針 ${ }^{1)}$ による最小深さ), 壁板内への定着 長さは $20 \mathrm{~d}_{\mathrm{a}}(=12 \mathrm{~cm})$ で, 頭ナット付きとした。 

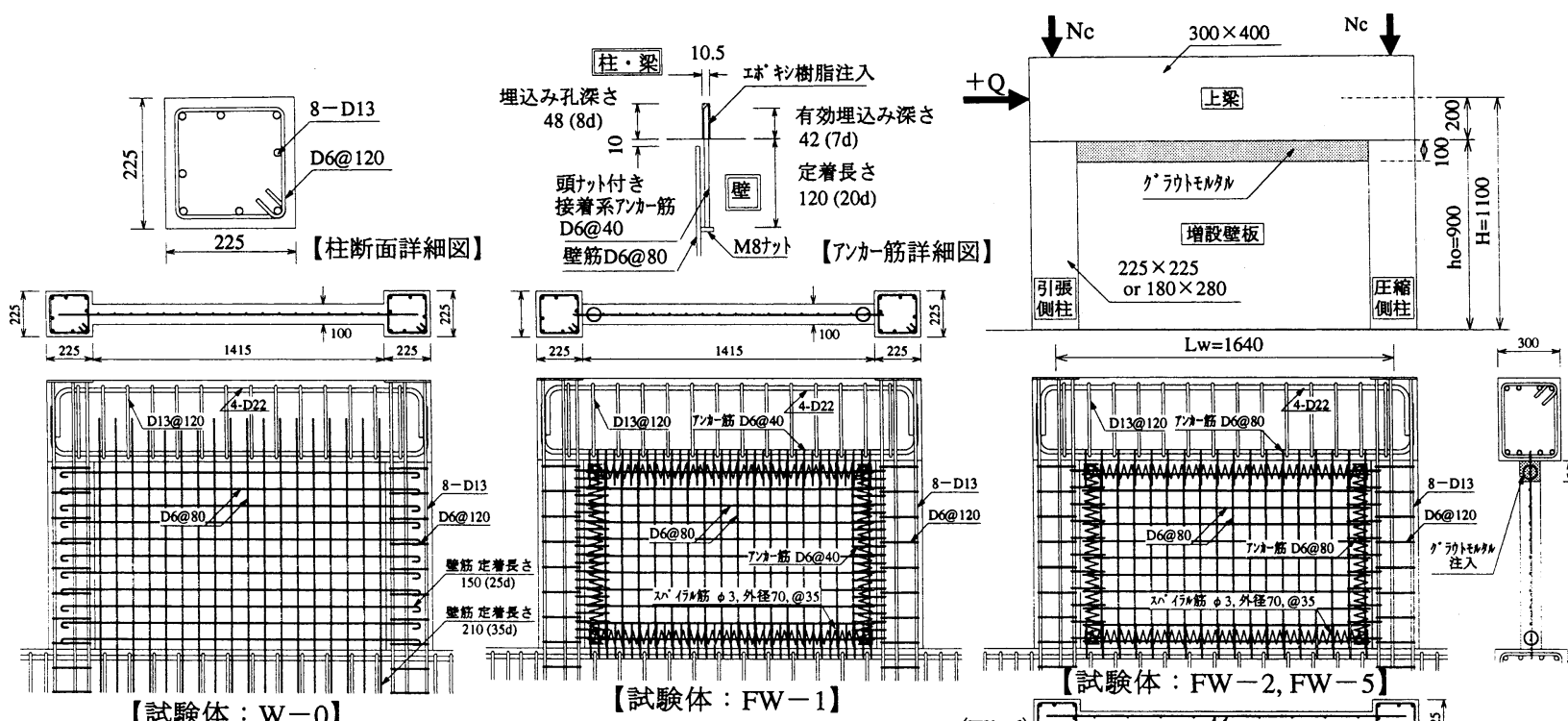

【試験体：W-0】

【試䙵体：FW-1】
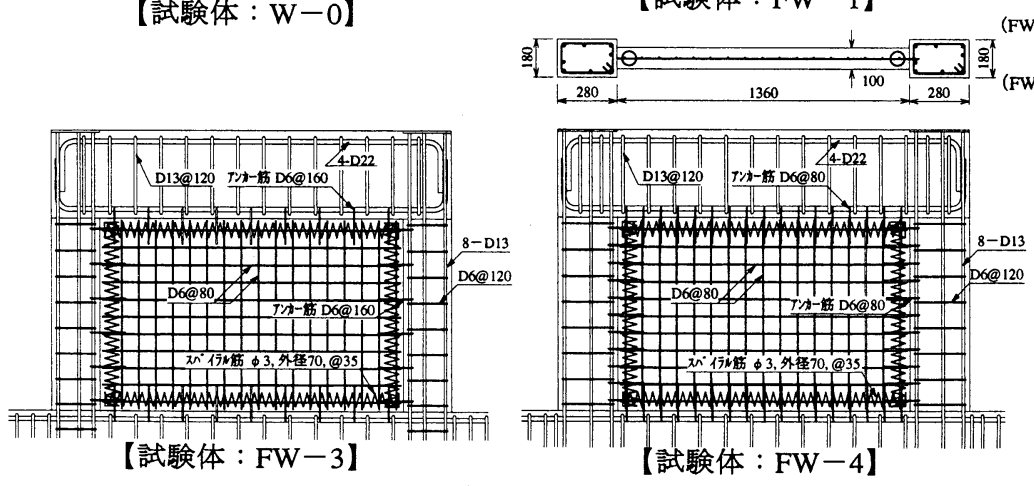

【試験体 : FW-2, FW-5】

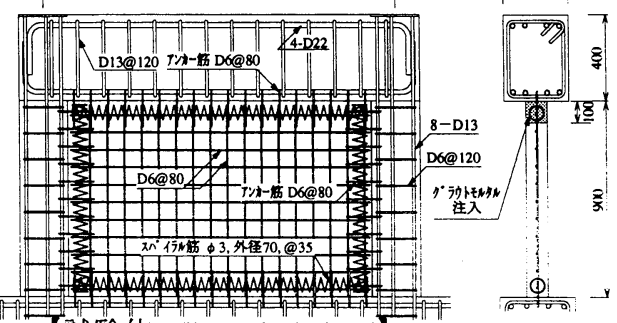

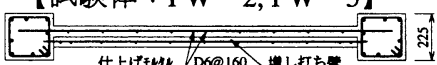
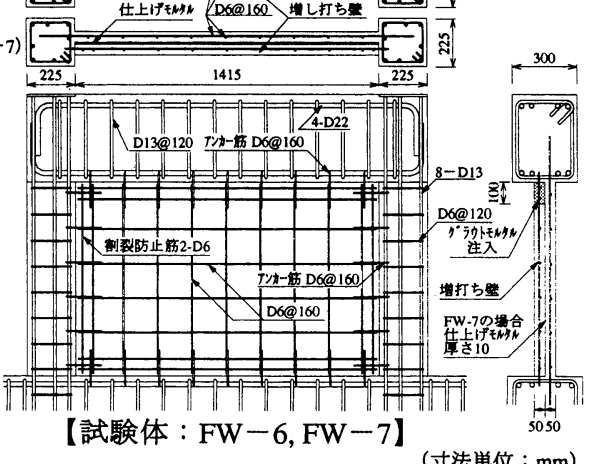

(寸法単位 : mm)

図-1＼cjkstart試験体の形状寸法および配筋

表-1 実験概要

\begin{tabular}{|c|c|c|c|c|c|c|c|c|c|c|c|}
\hline \multirow{3}{*}{ 試験体 } & \multirow{2}{*}{\multicolumn{2}{|c|}{$\begin{array}{l}\text { 壁厚 } \\
(\mathrm{cm}) \\
\end{array}$}} & \multirow{3}{*}{$\begin{array}{l}\text { 柱 } \\
\text { 断面 } \\
(\mathrm{cm})\end{array}$} & \multirow{2}{*}{\multicolumn{2}{|c|}{$\begin{array}{c}\mathrm{Fc} \\
(\mathrm{MPa})\end{array}$}} & \multirow{2}{*}{\multicolumn{2}{|c|}{ アンカー筋 }} & \multirow{3}{*}{$\begin{array}{c}\text { 仕上げ } \\
\text { モルタル } \\
\text { の有無 }\end{array}$} & \multicolumn{3}{|c|}{ 実験結果 } \\
\hline & & & & & & & & & \multirow{2}{*}{$\begin{array}{c}\mathrm{Qmax} \\
(\mathrm{kN})\end{array}$} & \multirow{2}{*}{$\begin{array}{l}\mathrm{Rm} \\
(\%)\end{array}$} & \multirow{2}{*}{$\begin{array}{l}\mathrm{Ru} \\
(\%)\end{array}$} \\
\hline & 既存 & 堌設 & & 骨組 & 壁板 & 配置 & $\mathrm{p}_{\mathrm{a}}(\%)$ & & & & \\
\hline W-0 & 10 & 0 & \multirow{4}{*}{$\begin{array}{c}22.5 \\
\times 22.5\end{array}$} & \multirow{8}{*}{21} & \multirow{5}{*}{21} & - & - & \multirow{7}{*}{ 無 } & 1104 & 0.77 & 0.99 \\
\hline FW-1 & \multirow{5}{*}{0} & \multirow{5}{*}{10} & & & & 1-D6@40 & 0.8 & & 982 & 0.50 & 1.68 \\
\hline FW-2 & & & & & & 1-D6@80 & 0.4 & & 834 & 0.45 & 1.75 \\
\hline FW-3 & & & & & & 1-D6@160 & 0.2 & & 883 & 0.50 & 1.38 \\
\hline FW-4 & & & $18 \times 28$ & & & & & & 913 & 0.50 & 1.52 \\
\hline FW-5 & & & & & 36 & $\cos 80$ & & & 939 & 0.50 & 1.54 \\
\hline FW-6 & \multirow{2}{*}{5} & \multirow{2}{*}{5} & $\begin{array}{c}22.5 \\
\times 22.5\end{array}$ & & \multirow{2}{*}{21} & \multirow{2}{*}{ 1-D6@160 } & 0.4 & & 1070 & 0.74 & 1.03 \\
\hline FW-7 & & & & & & & & 有 & 1072 & 0.45 & 1.04 \\
\hline
\end{tabular}

（注） 1 ） $\mathrm{Fc}$ ：コンクリートの設計基準強度, $\mathrm{p}_{\mathrm{a}}=\mathrm{a}_{\mathrm{a}} /\left(\mathrm{t}_{\mathrm{w}} \mathrm{S}_{\mathrm{a}}\right)$ : アンカー筋比 $\mathrm{a}_{\mathrm{a}}, \mathrm{S}_{\mathrm{a}}$ ：1組のアンカー筋の断面積掞よびピッチ, $\mathrm{t}_{\mathrm{w}}$ : 壁板の厚さ

2 ) Qmax : 最大耐力, Rm : Qmax時層間変形角

$\mathrm{Ru}$ ：限界層間変形角 (0.8Qmax耐力低下時の層間変形角)

\section{（3 増設壁板上部の処置方法}

増設壁板上部は上梁下面より $10 \mathrm{~cm}$ までコンクリートを打設し，コンクリ 一ト上端のレイタンスを除去した後, 梁下面まで無収縮グラウトモルタルを 注入し，梁下面と増設壁板上端の間に 乾燥収縮による隙間が生じないように した。また，既存柱，梁と増設壁板の 接合面はチッピングにより目荒しを行 った。

\section{(4) 割裂防止筋}

割裂防止筋としては, 増設壁試験体 FW-1〜FW-5ではスパイラル筋（ $\phi$

\section{表一3 鉄筋の引張試験結果}

\begin{tabular}{c|c|c|c|c}
\hline \multicolumn{2}{c|}{ 種別 } & $\begin{array}{c}\sigma \mathrm{y} \\
(\mathrm{MPa})\end{array}$ & $\begin{array}{c}\sigma \mathrm{u} \\
(\mathrm{MPa})\end{array}$ & $\begin{array}{c}\text { 伸び } \\
(\%)\end{array}$ \\
\hline \hline $\begin{array}{c}\text { 帯筋, 壁筋 } \\
\text { アンカー筋 }\end{array}$ & $\mathrm{D} 6$ & 408 & 531 & 26 \\
\hline 柱主筋 & $\mathrm{D} 13$ & 328 & 466 & 28 \\
\hline スパイラル筋 & $\phi 3$ & 466 & 481 & 16 \\
\hline
\end{tabular}


3-外径 70mm-@35mm, ps $=0.40 \%)$, 増打ち壁試験体 FW-6，FW-7では端部補強筋2-D6を配置した。ここに, $\mathrm{p}_{\mathrm{s}}=\mathrm{a}_{\mathrm{s}} /\left(\mathrm{t}_{\mathrm{w}} \mathrm{s}\right), \mathrm{a}_{\mathrm{s}} ， \mathrm{~s} ： 1$ 組のスパイラル筋の断面積扔よ びピッチ, $\mathrm{t}_{\mathrm{w}}$ : 壁板の厚さ。

(5)増打ち壁試験体の新旧壁接合面の処置方法

FW-6，FW-7 ともに，新旧壁接合面にはジベル筋を配 置せず，増打ち壁板コンクリート打設に際して，既存壁 コンクリート面または仕上げモルタル面に水湿しを行っ た。なお，既存壁コンクリート面はワイヤブラシにより 目荒しを行った。

\section{(6)仕上げモルタルの施工方法}

FW-7では, 仕上げモルタル塗りの施工に際して, 吸 水調整剤を既存壁コンクリート面に塗布し，仕上げモル タルの塗り厚は $10 \mathrm{~mm}$ （1層）とした。なお，FW-7は，

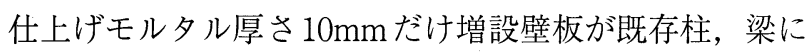
対して偏心して取り付いている

\section{3 使用材料}

コンクリート，無収縮グラウトモルタル，仕上げモル タルの強度試験結果を表一 2 , 鉄筋の引張試験結果を 表ー3に示す。

\section{3. 実験方法}

本実験では，図一2に示すように，両側柱に一定軸力 $\mathrm{N}_{\mathrm{c}}\left(2 \mathrm{~N}_{\mathrm{c}}=530 \mathrm{kN}\right)$ を加えた状態で，上部梁の中心軸に 水平力を加力した。その際, 試験体頂部の水平変形に追 随できるように, 軸力載荷用の油圧ジャッキの底部にニ ードル・ローラーを挿入した。

載荷履歴は, 各サイクルの層間変形角 $\mathrm{R} の$ 目標上下限 值を $\pm(0.05 ， 0.2 ， 0.5 ， 1.0 ， 1.5 ， 2.0 ， 2.5) \% \mathrm{rad}$.とした 正負繰返し載荷を 3 回ずつ行った後, 正加力方向に単調 載荷することとした。ただし，層間変形角は， $\mathrm{R}=\delta \mathrm{h}$ $/ \mathrm{H}_{\mathrm{a}}$ として算定した。ここに， $\delta \mathrm{h}, \mathrm{H}_{\mathrm{a}}$ ：壁脚部から加力 点までの水平変形量㧍よび高さ。

変位量の測定項目は, 層間変形角, 側柱の軸方向変形 量, 各部ずれ量（図-2参照）であり,ひずみ度の測定 部位は，柱主筋，柱带および壁筋である。

\section{4. 実験結果および考察}

\section{1 荷重一変形性状および破壊性状}

各試験体の $\mathrm{Q}-\mathrm{R}$ 関係と破壊状況を図一 3 と図 -4 に，実験因子ごとの $\mathrm{Q}-\mathrm{R}$ 関係の包路線を図一 5 に示す。 試験体W-0, FW-1, FW-6 およびFW-7では, 油圧ジャ ッキの最大容量の制限より約 $-1000 \mathrm{kN}$ で負加力側の最 大耐力が頭打ちとなったので, 目標層間変形角に達して いないサイクルがある。図一 3 中に併記した限界層間変 形角 Ruは, 最大耐力の $80 \%$ に耐力が低下したときの層 間変形角と定義した。

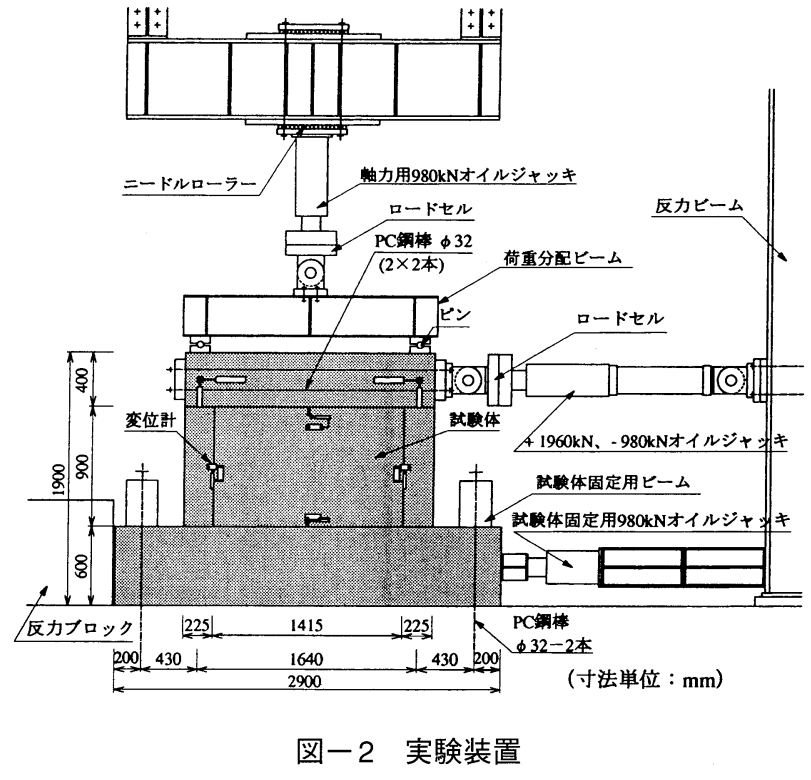

4.1.1一体打ち壁試験体（W-0）

本試験体は, 壁板のせん断ひび割れ, 柱脚部主筋の引 張降伏と压縮降伏が発生した後， $\mathrm{R}=0.77 \% \mathrm{rad}$.時に最 大耐力に達し, その後, 引張側柱頭部, 圧縮側柱脚部お よび壁板のせん断ひび割れに沿ってコンクリートが圧壊 し，耐力が急激に低下した。

\subsection{2 増設壁試験体（FW-1～FW-5）}

(1)アンカー筋量の影響 (FW-1〜 FW-3)

本試験体は, 柱主筋の引張降伏と圧縮降伏が発生した 後， $\mathrm{R}=0.45 \sim 0.50 \% \mathrm{rad}$. 時に最大耐力に達した。最大 耐力までは，アンカー筋量が少ないほど, 既存柱, 梁と 壁板の界面ひび割れおよび弓張側柱頭部のせん断ひび割 れの発生時期が早く, 壁板のせん断ひび割れの発生時期 が遅くなった。

最大耐力後は, 引張側と圧縮側柱頭部のせん断ひび割 れ幅が拡大するとともに，上梁と増設壁界面のずれ変形 が著しくなり，耐力が低下した。ただし，FW-1，FW-2 ではグラウトモルタル部，FW-3では壁板コンクリート 上部の損傷が著しくなった。すなわち，アンカー筋量が 多いと，アンカー筋から伝達されるせん断力によってグ ラウトモルタル部が損傷し, アンカー筋量が少ないと, 引張側柱頭部まわりより壁板に直接伝達されるせん断力 の作用によって壁板コンクリート上部の損傷が著しくな ったと考えられる。グラウトモルタル部の損傷は，スパ イラル筋の外部のみに発生し, 内部ではみられなかっ た。

最大耐力は, FW-1よりも FW-2の方が小さく, FW-2 と FW-3 は大差なく, FW-1 の最大耐力は一体打ち壁W0の $90 \%$ 程度となった。すなわち, 増設耐震壁の最大耐 力は, アンカー筋がある程度以上配置された場合, アン カー筋量に依存するが，アンカー筋が少ないと，アンカ 一筋量にあまり係わらない。後者の理由は, 引張側柱頭 


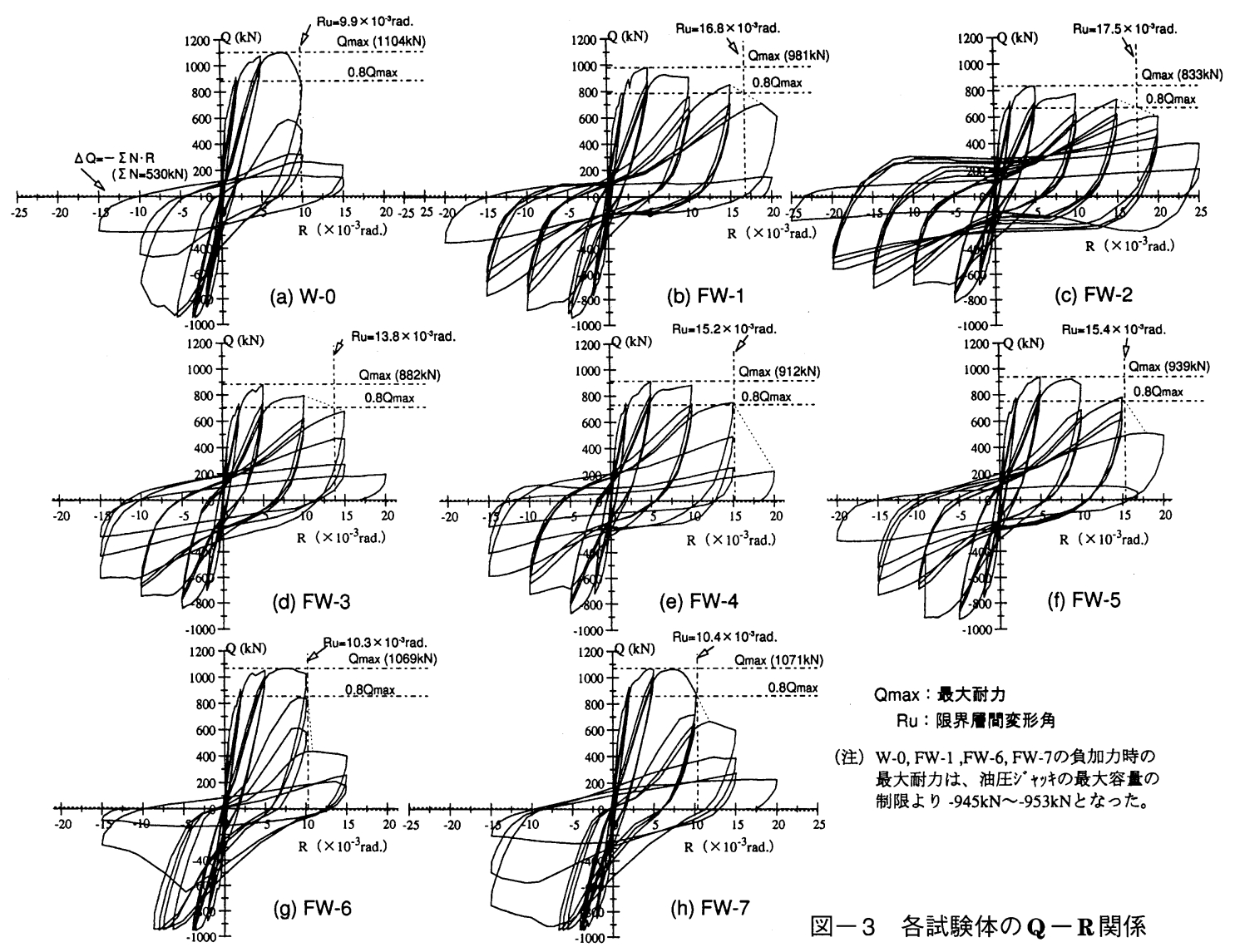

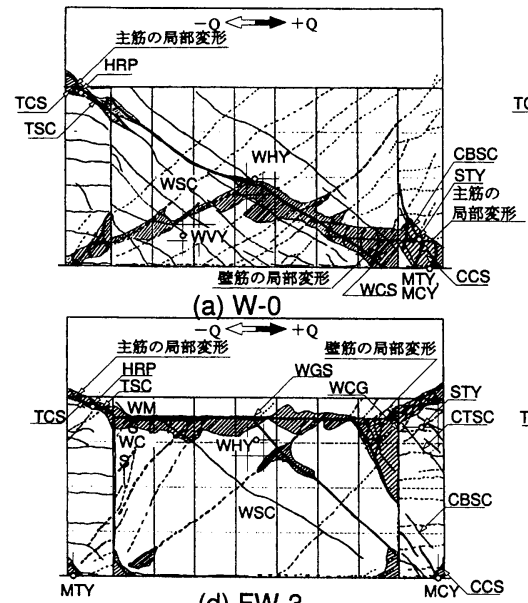

(d) FW-3
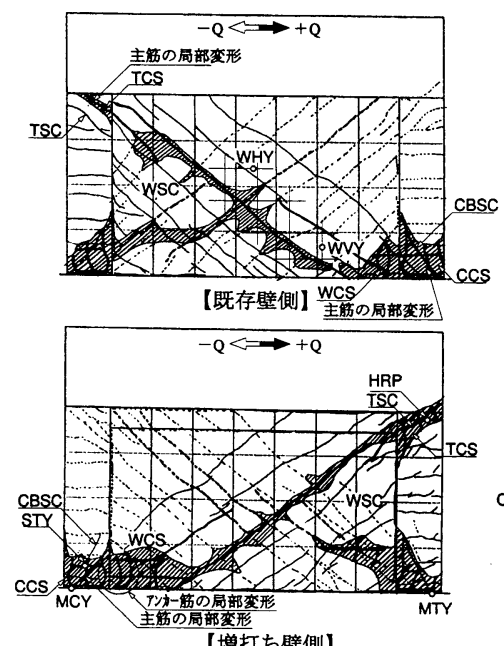

(g) FW-6

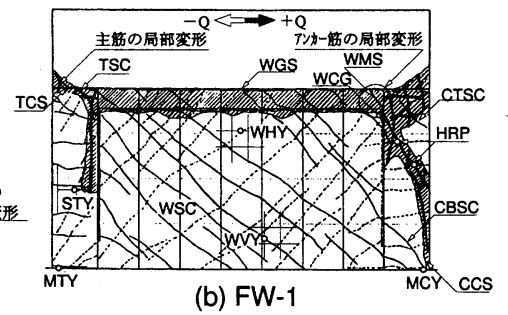

(b) FW-1

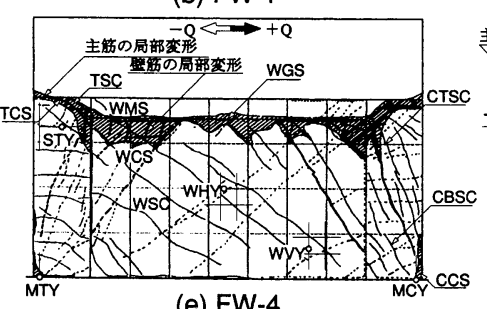

(e) FW-4

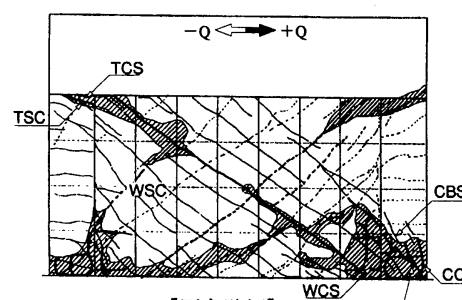

【既存壁側】主顺の局部等形

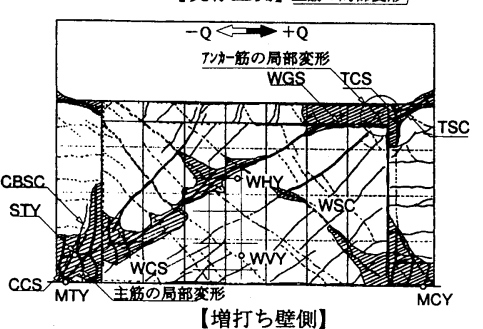

(h) FW-7
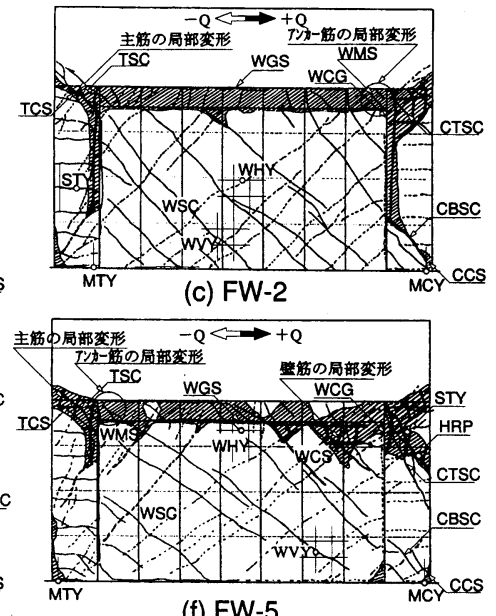

(f) FW-5

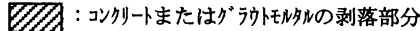

$\underline{\mathbb{Z}}$ : 正加力時 …. : 負加力時

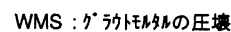

（せん断ひひ制れ）WGS:上粱と壁板のずれ変形 WSC : 壁板 WCG : 壁板と柱倒面闻の際間 TSC : 引根倒の柱頚 HRP : 柱带施の破断

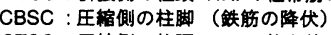
CTSC : 圧縮側の柱頭 MTY : 柱主筋の引張降伏

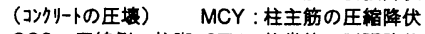
CCS : 压縮側の柱脚 STY : 柱带餙の引張降伏

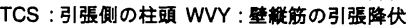
WCS : 壁板 WHY : 壁模䥻の引監降伏

(注) MC(T)Y, STY,WV(H)Y: 柱青等、带䇤

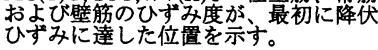


部と圧縮側柱脚部を結ぶ対角線上の圧縮スト ラットの作用が卓越したためと考えられる。

増設壁の限界層間変形角 Ruは，一体打ち 壁の場合よりも増大した。これは, 既存柱, 梁と増設壁板が完全に一体化されていない等 の理由によると考えられる。また，両側柱が 損傷して, 材軸方向縮みが生じたことに伴い, 増設壁板が圧縮軸力を負担したと推測される が，このことも，増設壁の限界層間変形角が 増大した一因と考えられる。ただし，アンカ 一筋が少ない FW-3 の限界層間変形角は, FW-1 とFW-2の場合よりも減少した。

(2)柱断面形状およびコンクリート強度の 影響（FW-4 と FW-5）

長方形断面柱の場合, 正方形断面柱に比べ て, 最大耐力は $10 \%$ 程度増大した。これは, 両者の側柱による壁板に対する拘束度合いの 差に起因すると考えられる。また，壁板コン クリート強度が高い場合, 最大耐力は $10 \%$ 程度増大した。これは, 増設壁板の対角圧縮 ストラットの効果により, 壁板コンクリート 強度の増大が増設耐震壁の最大耐力に寄与し たためと考えられる。

長方形断面柱の場合ならびに壁板コンクリ 一ト強度が高い場合, 正方形断面柱ないしは 普通強度の場合に比べて, 限界層間変形角は 減少した。これは, 側柱に明瞭なせん断ひび 割れが発生したことや引張側柱頭部から圧縮 側柱頭部にかけて損傷が集中したことと関連 すると考えられる。

\subsection{3 増打ち壁試験体（FW-6 と FW-7）}

増打ち壁の最大耐力および変形性能は, 仕 上げモルタルの有無に係わらず，一体打ち壁 の場合とほぼ一致した。ただし，仕上げモル タルが残存したFW-7では, 最大耐力後, 上 梁と増打ち壁上部の間でずれ変形が認められた。

\section{2 既存上部梁と増設壁板のずれ量}

既存上部梁と増設壁板のずれ量 $\delta_{\mathrm{jhu}}$ と層間変形角 Rの 関係を図一 6 に示す。 $\delta_{\mathrm{jhu}}$ は, 図ー 2 に示した変位計を 用いて測定したグラウトモルタル部を含めた間のずれ量 であり，これについて特筆すべき事項を以下に示す。

1) 既存柱, 梁と増設壁板間のずれ量は, アンカー筋量 が少ないほど, 最大耐力以降, 進展度合いが大きくな る傾向があった。

2 ) 柱断面形状によるずれ量の差異は認められなかっ た。

3 ）壁板コンクリート強度が高いと, ずれ量が減少する 傾向があった。

4) 仕上げモルタルが残存しない増打ち試験体 FW-6で

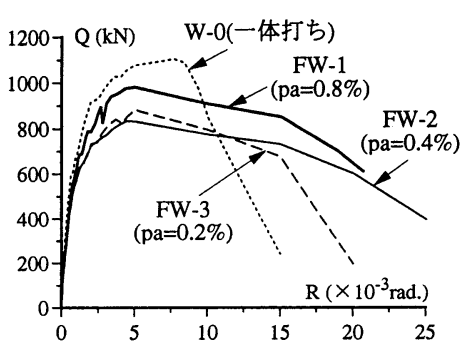

(a) アンカー筋量の影響

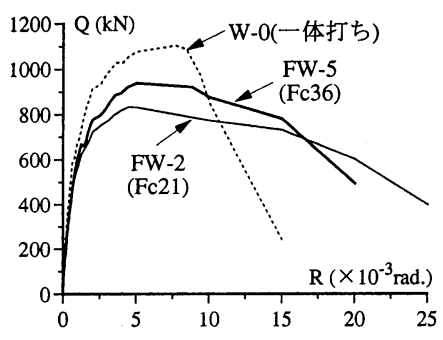

（c）壁板コンクリート強度の影響

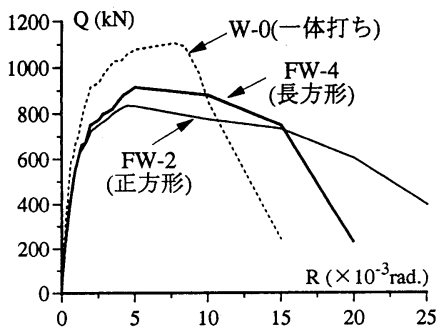

(b) 柱断面形状の影響

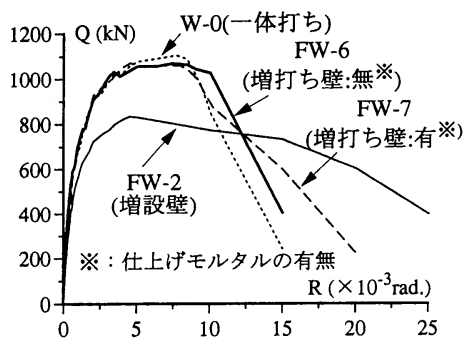

（d）增打ち壁と仕上げモルタルの影響

\section{図－5 実験因子ごとの $\mathbf{Q}-\mathbf{R}$ 関係の包絡線}

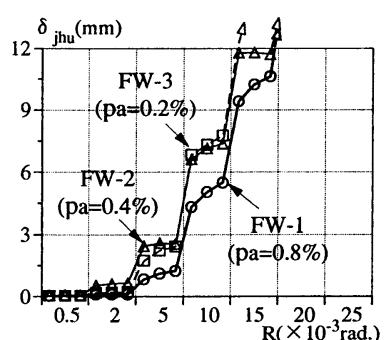

(a) アンカー筋量の影響

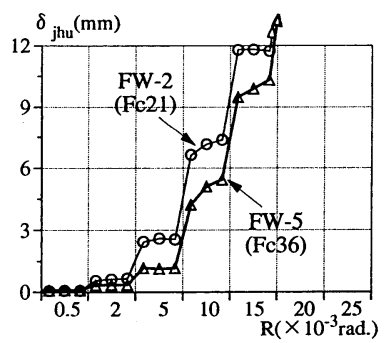

(c) 壁板コンクリート強度の影数

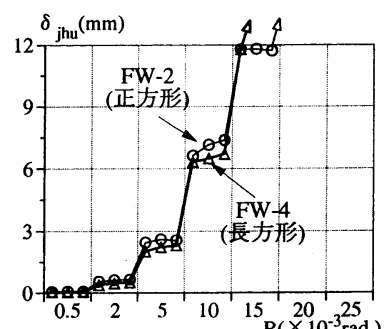

(b) 柱断面形状の影響

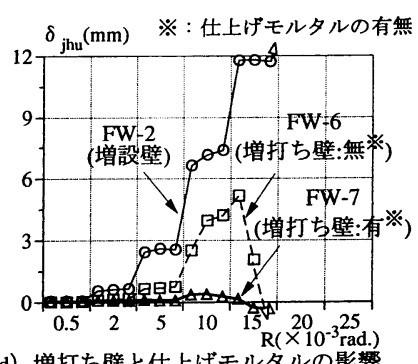

（d）増打ち壁と仕上げモルタルの影響

図一6 既存上部梁と増設壁のずれ量 $\delta_{\mathrm{jhu}}$ と層間変形角 $\mathbf{R}$ の関係

は，ずれ量はほとんど発生しなかった。

5 ）仕上げモルタルが残存した FW-7では, 最大耐力以 降，ずれ量が発生した。ただし，その值は，増設壁試 験体FW-2 の概ね $1 / 2$ 程度であり, 耐力が急激に低下 した時点では減少した。

\section{5. 終局耐力の評価}

\section{1 増設耐震壁の終局曲げ耐力}

(1)評価式

増設耐震壁の終局曲げ耐力 $\mathrm{M}_{\mathrm{wu}}$ は, 壁縦筋の応力度が アンカー筋の引抜き耐力に支配されるとし，下式のよう に，耐震診断基準式 ${ }^{3)}$ の壁縦筋の項にアンカー筋によっ て制限される壁縦筋の有効率 $\gamma_{\mathrm{a}} \beta_{\mathrm{v}}$ を乗じて算定する。 
$\beta_{\mathrm{v}}$ は壁縦筋の降伏耐力に対するアンカー筋の引抜き耐 力の比率， $\gamma_{\mathrm{a}}$ は実験值との適合性を考慮して定められ る低減係数であり， $\beta_{\mathrm{v}} \leqq 1 ， \gamma_{\mathrm{a}} \leqq 1$ とする。

$$
\begin{aligned}
& \mathrm{M}_{\mathrm{wu}}=\left\{\mathrm{a}_{\mathrm{ct}} \sigma_{\mathrm{cy}}+0.5\left(\gamma_{\mathrm{a}} \beta_{\mathrm{v}} \Sigma \mathrm{a}_{\mathrm{w}} \sigma_{\mathrm{wy}}+\mathrm{N}_{\mathrm{w}}\right)\right\} \ell_{\mathrm{w}} \\
& { }_{\mathrm{w}} \mathrm{Q}_{\mathrm{mu}}=\mathrm{M}_{\mathrm{wu}} / \mathrm{H}_{\mathrm{wa}} \\
& \beta_{\mathrm{v}}=\Sigma \mathrm{T}_{\mathrm{au}} / \Sigma \mathrm{a}_{\mathrm{w}} \sigma_{\mathrm{wy}}
\end{aligned}
$$

ここに, $a_{\mathrm{ct}}, \sigma_{\mathrm{cy}}$ : 引張側柱主筋全断面積および降伏強度

$\sum \mathrm{a}_{\mathrm{w}}, \sigma_{\mathrm{wy}}$ : 壁縦筋全断面積および降伏強度

$\ell_{\mathrm{w}}$ : 両側柱の中心間距離

$\mathrm{H}_{\mathrm{wa}}$ ：壁脚部から水平力作用位置までの高さ

$\mathrm{N}_{\mathrm{w}}$ : 両側柱軸力の和

$\Sigma T_{\text {au }}$ : 下梁上面に配置されたアンカー筋の引張 耐力の総和

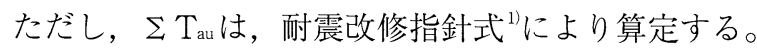

(2)実験值と計算值の比較

最大耐力実験值 $\mathrm{Q}_{\max }$ と 終局曲げ耐力計算值 $\mathrm{w}_{\mathrm{mu}}$ の関係 を図ー7に示す。同図中には，一体打ち試験体W-0の実 験值と計算值を併示した。また, 計算値は, 低減係数 $\gamma$ a を 0.7 として算定した。

検討対象は，本実験の FW-1 FW5 と既往実験のうち 接着系アンカーを用い論文中で曲げ降伏先行型と記載さ

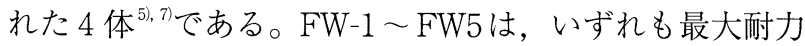
到達前に引張側柱脚部主筋が引張降伏していることか ら, 曲げ降伏が先行したとみなした。既往実験の 4 体は, いずれも柱主筋量が比較的少ない試験体である（ $\mathrm{p}_{\mathrm{g}}=$ $1.3 \%) 。$

同図に示すように，低減係数 $\gamma_{\mathrm{a}}$ を 0.7 とすると，終局 曲げ耐力は概ね妥当に評価される。ただし，FW-1〜 FW5 は，最大耐力が終局せん断耐力によって支配され ていると考えられるため, 終局曲げ耐力計算值は, 最大 耐力実験值よりもやや低くなっている（図一12参照）。

(3)最大耐力時の壁縦筋のひずみ度分布

一体打ち試験体 W-0 と増設壁試験体 FW-1 FW-5 の 最大耐力時の壁縦筋のひずみ度 $\varepsilon_{\mathrm{wvi}}$ の分布を図一 8 に示 す。

同図によると, 最大耐力時の壁縦筋の平均ひずみ度は, 壁筋の降伏ひずみ度 $\varepsilon_{\mathrm{y}}$ に対して, FW-3では $1 / 4$ 程度, それ以外の試験体では $1 / 2$ 程度の值に達している。一方, アンカー筋によって制限される壁縦筋の有効率 $\gamma_{\mathrm{a}} \beta_{\mathrm{v}}$ は, FW-3が 0.25 , それ以外の試験体が 0.51 と $0.45 て ゙$, 上記 の壁縦筋ひずみ度の值と概ね一致する。このことからも， 低減係数 $\gamma_{\mathrm{a}}$ の設定值は概ね妥当であると考えられる。

なお，増設壁試験体の壁脚部縦筋のうち側柱に近い箇 所のひずみ度が，一体打ち試験体に比べてかなり小さく なる場合がある。これは，アンカー筋の存在のほかに， 繰り返し加力などの影響を受けていると考えられる。

\section{2 増設耐震壁の終局せん断耐力}

5.2 .1 耐震改修指針による場合

耐震改修指針 ${ }^{1)}$ では，アンカー筋を考慮した増設耐震

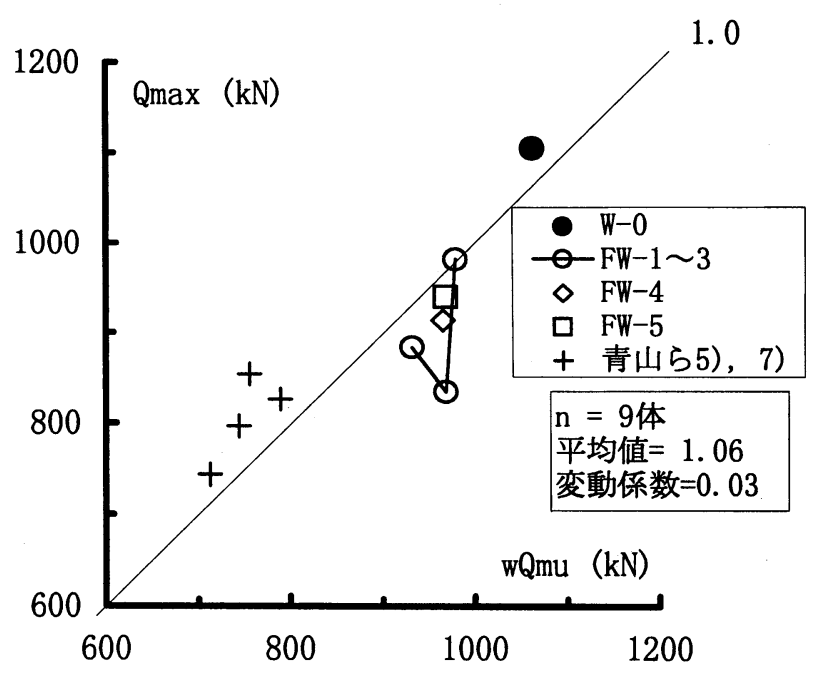

図一7 曲げ降伏先行型試験体の $\mathbf{Q}_{\max }-{ }_{\mathrm{w}} \mathbf{Q}_{\mathrm{mu}}$ 関係
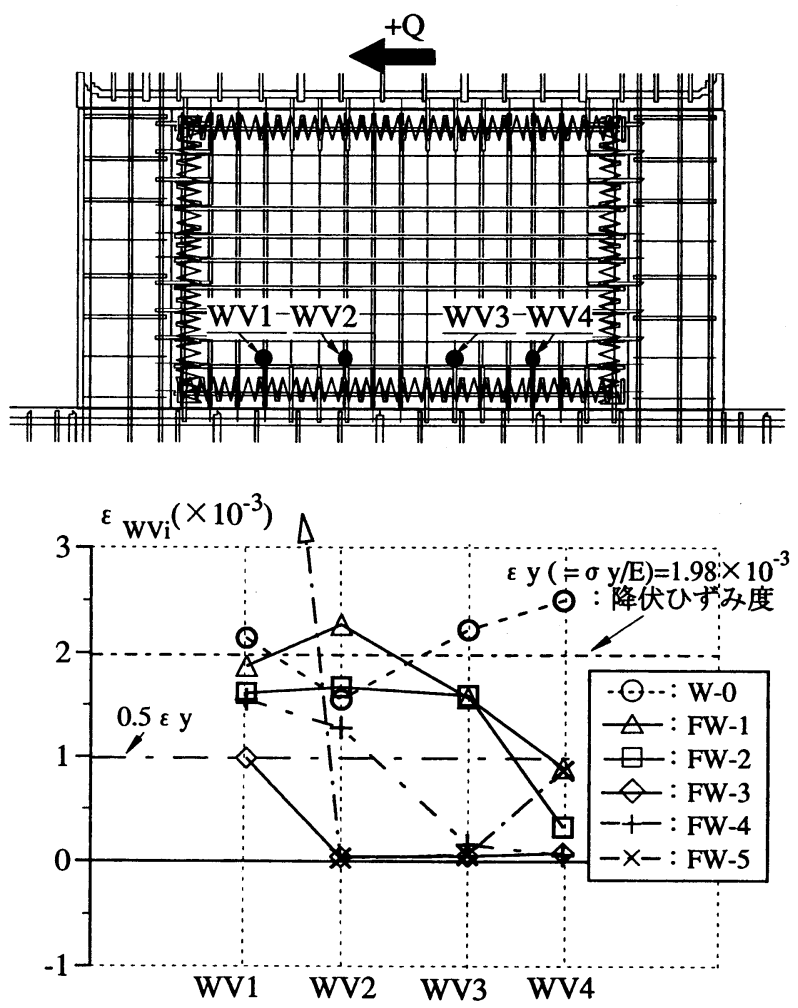

図一8 最大耐力時の壁縦筋のひずみ度分布

壁の終局せん断耐力を次式の $\mathrm{a} \mathrm{Q}_{\mathrm{su1}}, \mathrm{aQ}_{\mathrm{su} 2}$ のいずれか小さ い方で与えている。

$$
\begin{aligned}
& { }_{\mathrm{a}} Q_{\text {sul }}=Q_{\mathrm{wu}}+2 \alpha Q_{\mathrm{c}} \\
& { }_{\mathrm{a}} Q_{\mathrm{su} 2}=Q_{\mathrm{ju}}+{ }_{\mathrm{p}} \mathrm{Q}_{\mathrm{c}}+\alpha \mathrm{Q}_{\mathrm{c}}
\end{aligned}
$$

ここに， $\mathrm{Q}_{\mathrm{wu}}$ ：増設壁板 (内法部分) の終局せん断耐力

$Q_{\mathrm{ju}}$ ：上梁下面に配置されたアンカー筋のせん 断耐力の和

${ }_{\mathrm{p}} \mathrm{Q}_{\mathrm{c}}$ : 引張側柱頭部のパンチングシア耐力

$Q_{c}$ ：圧縮側柱の終局曲げまたはせん断耐力の

$$
\text { うち小さい方 }
$$

$\alpha$ : 変形状態を考慮した低減係数

柱せん断破壊の場合：1.0 


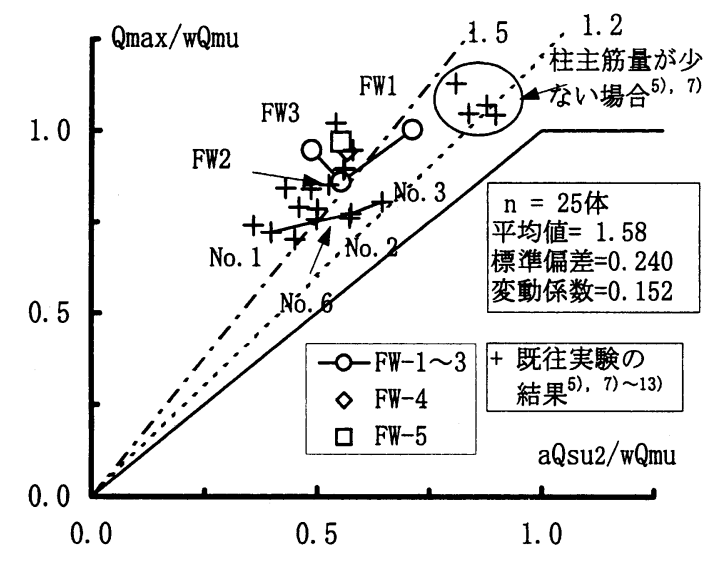

図一9 耐震改修指針による $\mathbf{Q}_{\mathrm{max}} / \mathrm{w} \mathbf{Q}_{\mathrm{mu}}-{ }_{\mathrm{a}} \mathbf{Q}_{\mathrm{su}} /{ }_{\mathrm{w}} \mathbf{Q}_{\mathrm{mu}}$ 関係

（注）当該実験因子のみが異なる実験結果を実線で結び表示した。

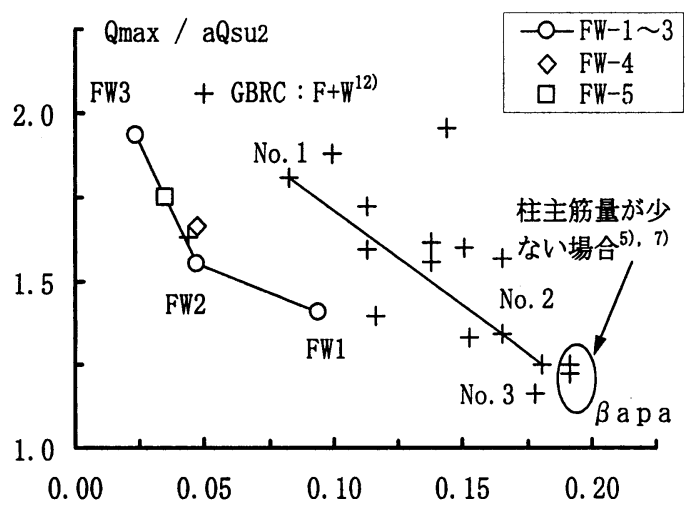

（a）アンカー筋量の影響

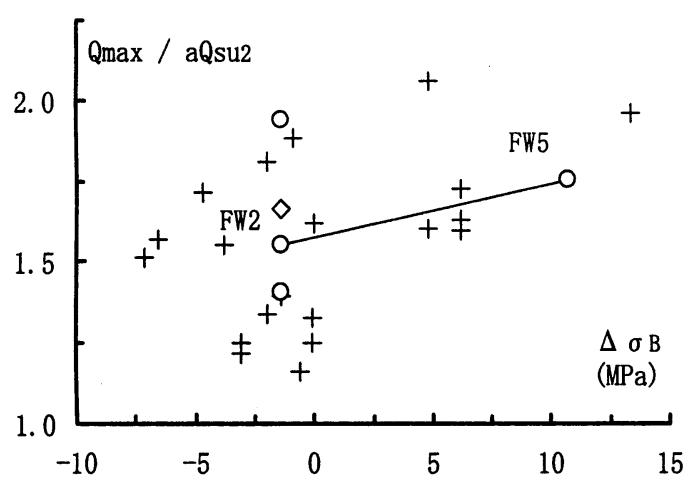

（b）増設壁板コンクリート強度の影響

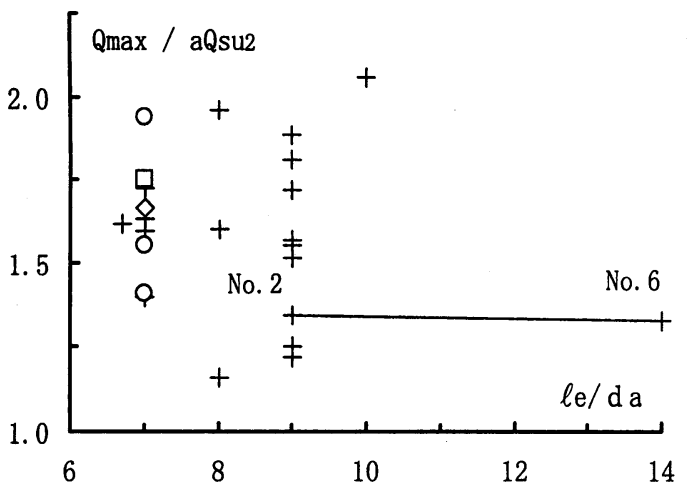

(c) $\ell \mathrm{e} / \mathrm{da}$ の影響

図ー 10 耐震改修指針による $\mathbf{Q}_{\mathrm{max}} / \mathbf{Q}_{\mathrm{a}} \mathbf{s u}_{\mathrm{su}}$ に及ぼす実験因子の 影響
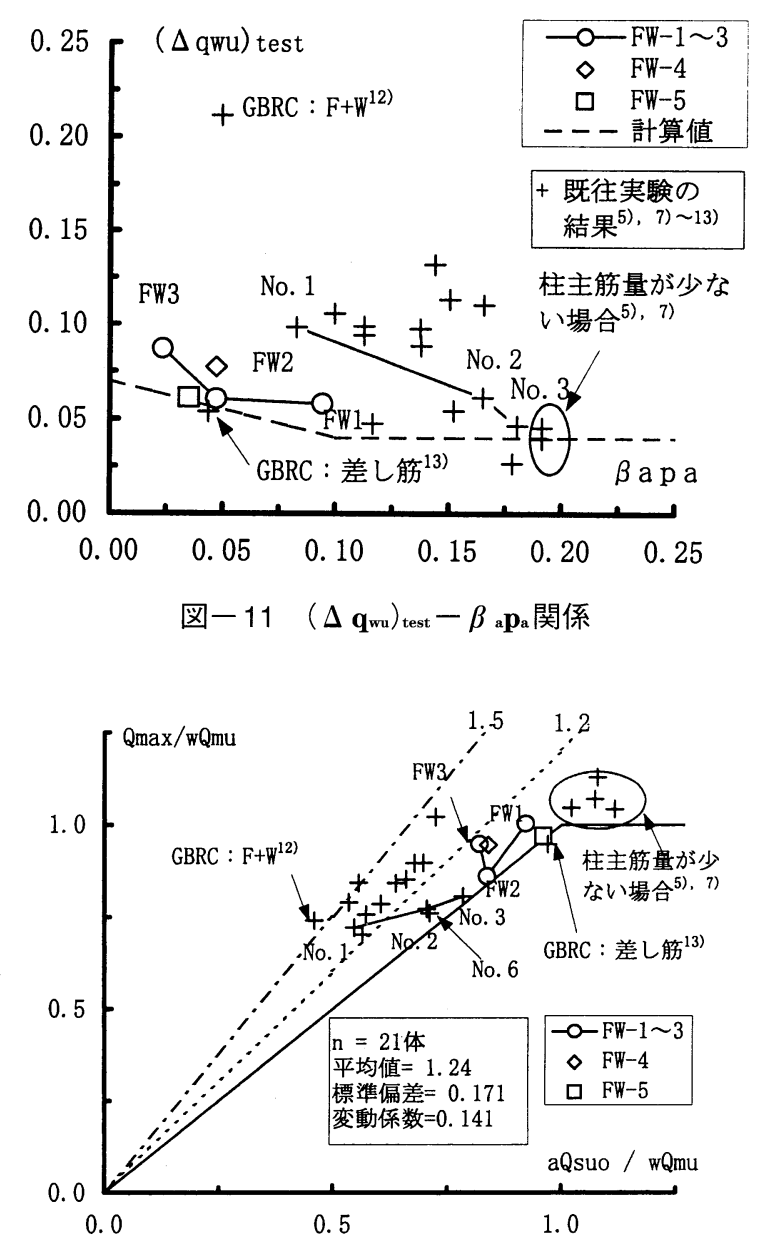

図ー12 修正式による $\mathbf{Q}_{\mathrm{max}} / \mathrm{w} \mathbf{Q}_{\mathrm{mu}}-{ }_{\mathrm{a}} \mathbf{Q}_{\mathrm{sud}} / \mathrm{w} \mathbf{Q}_{\mathrm{mu}}$ 関係

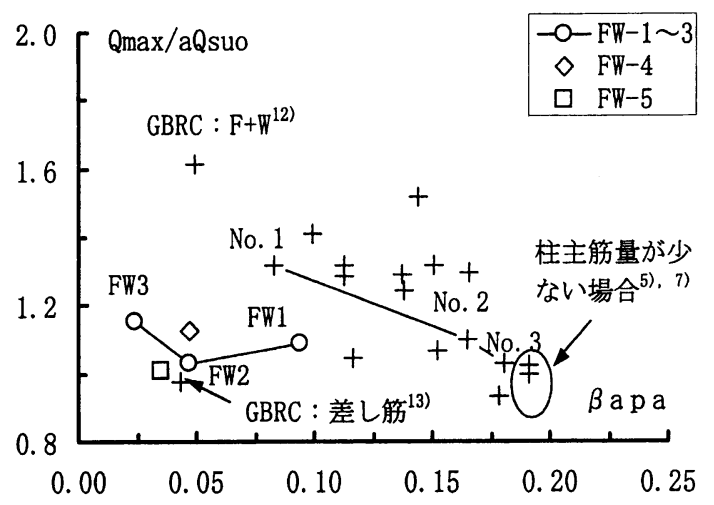

(a) アンカー筋量の影響

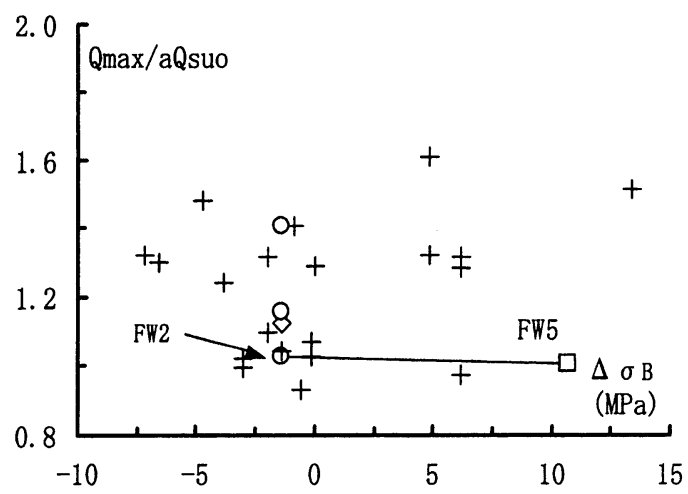

（b）増設壁板コンクリート強度の影響

図一13 修正式による $\mathbf{Q}_{\mathrm{max} / \mathrm{a}} \mathbf{Q}_{\mathrm{su}}$ に及ぼす実験因子の影響 
柱曲げ破壞の場合：0.7

耐震改修指針では式(4)の、Q ${ }_{\mathrm{sul}}$ の妥当性が示されてい ない等の理由により，ここでは，式(5)による終局せん 断耐力について検討する。

$\mathrm{Q}_{\max } /{ }_{\mathrm{w}} \mathrm{Q}_{\mathrm{mu}}-{ }_{\mathrm{a}} \mathrm{Q}_{\mathrm{su} 2} / \mathrm{wQ}_{\mathrm{mu}}$ 関係を図一9, $\mathrm{Q}_{\max } / \mathrm{aQ}_{\mathrm{a} u 2}$ に及ぼ す実験因子の影響を図一10に示す。同図中には，FW1 〜 FW5 と接着系アンカーを用いた既往の実験結果 ${ }^{5), 7) ~ 13) ~}$ を示した。同図中のNo. 1〜No. 3 とNo. $6^{10}$ は，アンカ 一筋量およびアンカー筋の埋め込み長さを実験因子とし た試験体であり，同図中の $\beta_{\mathrm{a}} \mathrm{p}_{\mathrm{a}}$ と $\Delta \sigma \mathrm{B}$ は下式により算 定した。

$$
\begin{aligned}
& \beta_{\mathrm{a}} \mathrm{p}_{\mathrm{a}}=\mathrm{p}_{\mathrm{a}} \sigma_{\mathrm{ay}} / \sigma_{\mathrm{B} 2} \\
& \Delta \sigma_{\mathrm{B}}=\sigma_{\mathrm{B} 2}-\sigma_{\mathrm{B} 1} \\
& \text { ここに, } \beta_{\mathrm{a}}=\sigma_{\mathrm{ay}} / \sigma_{\mathrm{B} 2} \\
& \mathrm{p}_{\mathrm{a}}=\mathrm{a}_{\mathrm{a}} /\left(\mathrm{t}_{\mathrm{w}} \mathrm{S}_{\mathrm{a}}\right): \text { アンカー筋比 } \\
& \mathrm{a}_{\mathrm{a}}, \mathrm{S}_{\mathrm{a}}: 1 \text { 組のアンカー筋の断面積およびピッチ } \\
& \mathrm{t}_{\mathrm{w}} \text { : 壁板の厚さ } \\
& \sigma_{\mathrm{ay}} \text { : アンカー筋の降伏強度 } \\
& \sigma_{\mathrm{B} 2} \text { : 壁板コンクリートの圧縮強度 } \\
& \sigma_{\mathrm{B} 1} \text { : 既存柱, 梁コンクリートの圧縮強度 }
\end{aligned}
$$

これによると，aQ $\mathrm{Qu}_{\mathrm{su} 2}$ の計算值は，いずれも安全側にな るが，アンカー筋量 $\beta$ a $\mathrm{p}_{\mathrm{a}}$ が少ないか, 既存躯体より壁 板コンクリート強度が大きいと過小に評価される。また， アンカー筋の有効埋め込み長さ $\ell_{\mathrm{e}}$ は, 最小埋め込み長 さ $7 \mathrm{~d}_{\mathrm{a}}$ 以上の場合， $\mathrm{Q}_{\max } / \mathrm{a}_{\mathrm{a} \text { su2 }}$ にあまり影響を及ぼさな w。

\section{2 .2 修正式による場合}

\section{(1)修正式の誘導}

耐震改修指針式によると, 前述のように, 終局せん断 耐力が過小評価になることがある。これは，主として， 増設壁板の負担せん断力のうち，アンカー筋により伝達 されるせん断力 $Q_{\mathrm{ju}}$ のほかに，対角圧縮ストラットの効 果が考慮されていないためと考えられる。そこで，次式 のように，壁板の圧縮ストラットによるせん断力増分 $\Delta$ $\mathrm{Q}_{\mathrm{wu}}$ を考慮し，終局せん断耐力 $\mathrm{a} \mathrm{Q}_{\text {suo }}$ 算定する。

$$
\begin{aligned}
& { }_{\mathrm{a}} \mathrm{Q}_{\text {suо }}=\mathrm{Q}_{\mathrm{ju}}+\Delta \mathrm{Q}_{\mathrm{wu}}+{ }_{\mathrm{p}} \mathrm{Q}_{\mathrm{c}}+\alpha \mathrm{Q}_{\mathrm{c}} \\
& \Delta \mathrm{Q}_{\mathrm{wu}}=\Delta \mathrm{q}_{\mathrm{wu}} \sigma_{\mathrm{B} 2} \ell_{\mathrm{wo}} \mathrm{t}_{\mathrm{w}}
\end{aligned}
$$

ここに, $\Delta \mathrm{q}_{\mathrm{wu}}$ : 無次元化せん断力増分 $\ell_{\text {wo }}$ : 壁内法長さ

ここで， $\Delta Q_{\mathrm{wu}}$ は, 増設壁板から既存梁および柱梁接 合部に伝達されるせん断力増分であると仮定している。 このような力の流れは, 図 -4 に示した実験結果の破壊 モードからも推測される。

次に，実験值の $\left(\Delta \mathrm{q}_{\mathrm{wu}}\right)_{\text {test }}$ を下式より算定する。

$\left(\Delta \mathrm{q}_{\mathrm{wu}}\right)_{\text {test }}=\left(\mathrm{Q}_{\max }-{ }_{\mathrm{a}} \mathrm{Q}_{\mathrm{su} 2}\right) /\left(\sigma_{\mathrm{B} 2} \ell_{\mathrm{wo}} \mathrm{t}_{\mathrm{w}}\right)$

図ー11に示すように， $\beta_{\mathrm{a}} \mathrm{p}_{\mathrm{a}}$ が小さいと, $\left(\Delta \mathrm{q}_{\mathrm{wu}}\right)_{\text {test }}$ は 増大する傾向がある。すなわち, アンカー筋量が少ない と, 圧縮ストラットの効果が大きくなると考えられる。 この結果を踏まえて，実験值に対して概ね安全側になる
ように, $\Delta \mathrm{q}_{\mathrm{wu}}$ を下式により算定する。

$$
\begin{aligned}
& \beta_{\mathrm{a}} \mathrm{p}_{\mathrm{a}}<0.1 \text { のとき, } \Delta \mathrm{q}_{\mathrm{wu}}=0.07-0.3 \beta_{\mathrm{a}} \mathrm{p}_{\mathrm{a}} \\
& \beta_{\mathrm{a}} \mathrm{p}_{\mathrm{a}} \geqq 0.1 \text { のき, } \Delta \mathrm{q}_{\mathrm{wu}}=0.04 \\
& \therefore \Delta \mathrm{Q}_{\mathrm{wu}}=\left(0.07 \sigma_{\mathrm{B} 2}-0.3 \mathrm{p}_{\mathrm{a}} \sigma_{\mathrm{ay}}\right) \ell_{\mathrm{wo}} \mathrm{t}_{\mathrm{w}} \\
& \text { または, } \Delta \mathrm{Q}_{\mathrm{wu}}=0.04 \sigma_{\mathrm{B} 2} \ell_{\mathrm{wo}} \mathrm{t}_{\mathrm{w}}
\end{aligned}
$$

また，式(12)を式( 8 )に代入すると，次式が得られる。

${ }_{\mathrm{a}} \mathrm{Q}_{\text {suo }}={ }_{\mathrm{w}} \tau_{\text {ju }} \ell_{\text {wo }} \mathrm{t}_{\mathrm{w}}+{ }_{\mathrm{p}} \mathrm{Q}_{\mathrm{c}}+\alpha \mathrm{Q}_{\mathrm{c}}$

$\beta_{\mathrm{a}} \mathrm{p}_{\mathrm{a}}<0.1$ のとき, $\tau_{\text {ju }}=0.07 \sigma_{\mathrm{B} 2}+\left(\eta_{\mathrm{a}}-0.3\right) \mathrm{p}_{\mathrm{a}} \sigma_{\text {ay }}$

$\beta_{\mathrm{a}} \mathrm{p}_{\mathrm{a}} \geqq 0.1$ のとき, w $\tau_{\text {ju }}=0.04 \sigma_{\mathrm{B} 2}+\eta_{\mathrm{a}} \mathrm{p}_{\mathrm{a}} \sigma_{\text {ay }}$

ここに, $\eta_{\mathrm{a}}$ : アンカー筋のせん断低減係数

耐震改修指針によると，アンカー筋のせん断強度がア ンカー筋自身の降伏せん断強度に支配される場合, $\eta_{\mathrm{a}}=$ 0.7 となる。

\section{(2)検討結果}

図ー 12 と図ー13に示すように，修正式による終局せ ん断耐力は，アンカー筋量および壁板コンクリート強度 に概ね係わらず，実験值に対して精度良く評価できた。 すなわち, ${ }_{\mathrm{a}} \mathrm{Q}_{\mathrm{suo}} /{ }_{\mathrm{w}} \mathrm{Q}_{\mathrm{mu}}<1$ の 21 体の $\mathrm{Q}_{\max } /{ }_{\mathrm{a}} \mathrm{Q}_{\mathrm{suo}}$ の平均值は 1.24 , 変動係数 0.141 であり, 大凡, いずれも安全側に 評価されている。一方, ${ }_{\mathrm{a}} \mathrm{Q}_{\mathrm{suo}} / \mathrm{wQ}_{\mathrm{w} u}$ の值が大きくなると, $\mathrm{Q}_{\max } / \mathrm{aQ}_{\mathrm{asuo}}$ の值が小さくなる傾向がある。これは, 最大 耐力実験值が曲げ耐力の影響を受けているためと考えら れる。

なお，図中で差し筋と表記した試験体 ${ }^{13)}$ の計算值は実 験值よりもやや小さくなった。同試験体のアンカー筋は, 既存コンクリートに予め埋め込んだ差し筋であり，その 影響が現れたと考えられる。

\section{3 増打ち壁の終局せん断耐力}

(1)評価式

従来，増打ち壁の終局耐力の評価式は，実験検証例が 十分になく，明確に定まっていない。そのため，ここで

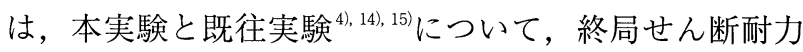
評価式の妥当性を検討する。その際, 終局せん断耐力は, 下式のように，既存部の一体打ち耐震壁と増打ち壁板自 身の終局せん断耐力の足し合わせが成り立つとする。

$$
{ }_{\mathrm{p}} \mathrm{Qsu}_{\mathrm{su}}={ }_{\mathrm{w}} \mathrm{Q}_{\mathrm{sul}}+{ }_{\mathrm{w}} \mathrm{Q}_{\mathrm{su}}{ }_{2}
$$

ここに, $\mathrm{pQ}_{\mathrm{su}}$ ：増打ち壁の終局せん断耐力

wQ $Q_{\text {sul }}$ : 既存耐震壁の終局せん断耐力

wQsu2：増打ち壁板自身の終局せん断耐力

ここで， ${ }^{\mathrm{w}} \mathrm{Q}_{\mathrm{sul}}$ は耐震診断基準式 ${ }^{3)} ，{ }^{\mathrm{w}} \mathrm{Q}_{\mathrm{su} 2}{ }^{2}$ は下式 ${ }^{2)} よ り$ 算定する。ただし，壁筋に係わる項は，壁筋量とアンカ 一筋量のいずれか小さい方で決定する。

$$
\begin{aligned}
{ }_{\mathrm{w}} \mathrm{Qu}_{\mathrm{su} 2}= & \left\{\sigma_{\mathrm{B} 2} / 20+0.5\left(\mathrm{p}_{\mathrm{w}} \cdot \sigma_{\mathrm{wy}}\right)_{2}\right\} \cdot \mathrm{t}_{\mathrm{w} 2} \cdot \ell_{\mathrm{wo}} \\
& \leqq 3.0 \cdot \mathrm{t}_{\mathrm{w} 2} \cdot \ell_{\mathrm{wo}}(\mathrm{kN})
\end{aligned}
$$

ここに, $\left(\mathrm{p}_{\mathrm{w}} \cdot \sigma_{\mathrm{wy}}\right)_{2}=\operatorname{Min}\left\{\mathrm{p}_{\mathrm{w} 2} \cdot \sigma_{\mathrm{wy} 2}, \mathrm{p}_{\mathrm{a}} \cdot \sigma_{\mathrm{ay}}\right\}$

$\sigma_{\mathrm{B} 2}$ : 増打ち壁板コンクリートの圧縮強度

$\mathrm{p}_{\mathrm{w} 2}, \sigma_{\mathrm{wy} 2}$ : 増打ち壁の壁筋比および降伏強度

$\mathrm{p}_{\mathrm{a}}, \sigma_{\mathrm{ay}}$ :アンカー筋比および降伏強度

$\mathrm{t}_{\mathrm{w} 2}$ : 増打ち壁板の厚さ 
表一4 増打ち壁の実験值と計算值

\begin{tabular}{|c|c|c|c|c|c|c|c|c|c|}
\hline \multirow{2}{*}{\multicolumn{2}{|c|}{ 試験体 }} & \multirow{2}{*}{$\begin{array}{c}\text { 実験結果 } \\
\text { Qmax } \\
(\mathrm{kN})\end{array}$} & \multicolumn{5}{|c|}{ 終局せん断耐力 } & \multirow{2}{*}{$\begin{array}{l}\text { Qmax } \\
\text { /wQsu }\end{array}$} & \multirow{2}{*}{$\begin{array}{l}\text { Qmax } \\
/ \mathrm{pQsu}\end{array}$} \\
\hline & & & $\begin{array}{c}\text { wQsu } \\
(\mathrm{kN})\end{array}$ & $\begin{array}{c}\text { wQsul } \\
(\mathrm{kN})\end{array}$ & $\begin{array}{c}\text { wQsu'2 } \\
(\mathrm{kN})\end{array}$ & $\begin{array}{c}\text { pQsu } \\
(\mathrm{kN})\end{array}$ & $\begin{array}{l}\text { pQsu } \\
\text { /wQsu }\end{array}$ & & \\
\hline \multirow{2}{*}{$\begin{array}{c}\text { 本 } \\
\text { 実験 }\end{array}$} & FW6 & 1070 & \multirow{2}{*}{692} & \multirow{2}{*}{507} & \multirow{2}{*}{180} & \multirow{2}{*}{687} & \multirow{2}{*}{0.99} & 1.55 & 1.56 \\
\hline & FW7 & 1072 & & & & & & 1.55 & 1.56 \\
\hline 4) & W-40W & 628 & 474 & 331 & 107 & 438 & 0.92 & 1.32 & 1.43 \\
\hline 14) & F-16 & 442 & 376 & 244 & 111 & 355 & 0.94 & 1.18 & 1.25 \\
\hline 15) & B & 943 & 643 & 478 & 147 & 625 & 0.97 & 1.47 & 1.51 \\
\hline
\end{tabular}

(注) 1) $\mathrm{Qmax}$ ：最大耐力実験值

2 ）wQsu：増し打ち壁との合計壁厚さが等しいとした一体打ち耐震壁の 終局せん断耐力（既存部コンクリート強度を用いた）

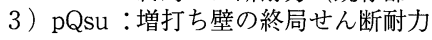

6。まとめ

1）増設耐震壁の最大耐力は, アンカー 筋がある程度以上配置された場合，ア ンカー筋量に依存するが，アンカー筋 が少ないと，増設壁板の圧縮ストラッ トの効果が大きく，アンカー筋量にあ まり係わらない。

2 ）増設壁試験体の限界層間変形角は, 一体打ち壁試験体の場合よりも増大し た。これは，既存柱，梁と増設壁板が 完全に一体化されていない等の理由に

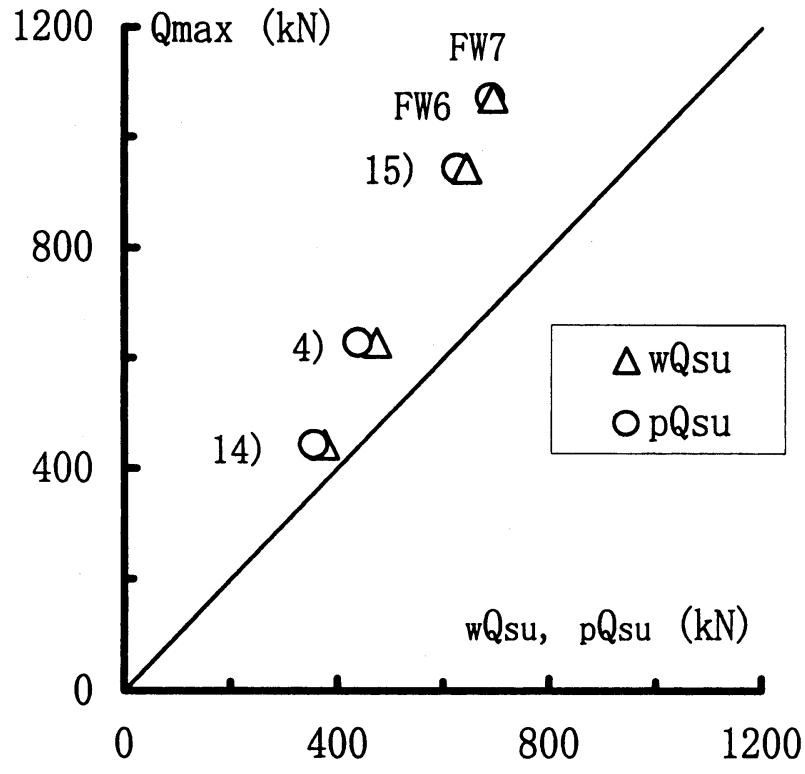

図一14 増打ち壁試験体の $\mathbf{Q}_{\max }-{ }_{\mathrm{w}} \mathbf{Q}_{\mathrm{su}},{ }_{\mathrm{p}} \mathbf{Q}_{\mathrm{su}}$ 関係

(2)検討結果

実験值と計算值の比較を表一 4 および図ー 14 に示す。 同図表中には，FW-6，FW-7 と既往実験4, 14, 15) の結果を 示すとともに，増打ち壁との合計壁厚さが等しいとした 一体打ち耐震壁の終局せん断耐力の計算值 ${ }_{\mathrm{w}} \mathrm{Q}_{\mathrm{su}}$ を併示し た。ただし，増打ち壁の既往実験では，接着系アンカー を用いたものはなく, 文献4)の実験ではアンカー筋を 配置せず，文献14)，15）の実験では金属系アンカーを用 いている。

これによると，いずれも増打ち壁の終局せん断耐力 ${ }^{\mathrm{p} Q \mathrm{su}}$ は，実験值に対して安全側に評価されている。式 (15)は，増打ち壁は一体打ち耐震壁と同様の破壊モード を形成すると仮定していることを意味する。しかしなが ら，文献4）の実験では，既存部壁板と側柱が増打ち壁 板の影響を受けて著しく損傷し，本実験の増打ち壁は一 体打ち耐震壁とほほ同様の破壊性状を示した。両者の差 異は，アンカー筋の種類やアンカー筋量などに起因する と推察されるが明確でない。そのため, 本式の適用に際 しては，本実験で採用した程度のアンカー筋量を打設す る必要があると考えられる。
よると考えられる。ただし，アンカー筋が少ないと， 引張側柱頭部から圧縮側柱頭部にかけて損傷が集中す るため, 限界層間変形角は減少した。

3 ）長方形断面柱の場合ならびに壁板コンクリート強度 が高い場合，正方形断面柱ないしは普通強度の場合に 比べて，それぞれ最大耐力は $10 \%$ 程度増大し，限界 層間変形角は減少した。これは，側柱による壁板に対 する拘束度合いの差や増設壁板の圧縮ストラットの効 果に起因すると考えられる。

4 ）増打ち壁の最大耐力および変形性能は，仕上げモル タルの有無に係わらず，一体打ち耐震壁とほほ一致し た。

5 ）増設耐震壁と増打ち壁の終局耐力の評価に関して, 下記の知見を得た。

a ）増設耐震壁の終局曲げ耐力は, アンカー筋によって 制限される壁縦筋の有効率を考慮することにより，概 ね妥当に評価できた。

b ）耐震改修指針式による増設耐震壁の終局せん断耐力 は, アンカー筋量 $\beta_{\mathrm{a}} \mathrm{p}_{\mathrm{a}}$ が少ないか, 既存躯体より壁 板コンクリート強度が大きいと過小評価となる。

c ）修正式による終局せん断耐力は，アンカー筋量およ び壁板コンクリート強度に係わらず，実験值に対して 精度良く評価できた。

d）増打ち壁の終局せん断耐力は, 既存部の一体打ち耐 震壁と増打ち壁板の終局せん断耐力を足し合わせるこ とにより安全側に評価できた。

なお，本研究では比較的剛な上部梁を有する増設耐震 壁を対象としているため, 本評価式の適用に際して, 非 連層の耐震壁などで上部梁の終局耐力が小さい場合に は，その影響を考慮する必要がある。

[謝 辞] 本研究は, 大阪市立学校建物耐震診断等判定 委員会の活動の一環として実施したものであり, 補強工 事は, ショーボンド建設侏)の協力を得た。関係者の皆様 方に感謝の意を表します。 
1）日本建築防災協会：既存鉄筋コンクリート造建築物の耐震 改修設計指針·同解説，平成 2 年

2) 日本コンクリート工学協会編：既存鉄筋コンクリート構造 物の耐震補強ハンドブック，技法堂，1984

3）日本建築防災協会：既存鉄筋コンクリート造建築物の耐震 診断基準・同解説，平成 2 年

4) 東端泰夫, 山口育雄, 菅野俊介, 長嶋俊雄, 藤村勝：既存 中低層 RC 建物の耐震壁補強方法に関する研究，(その 1 概 要および実験結果), (その 2 実験結果の検討), 日本建築 学会大会梗概集，構造，pp. 1451-1454，昭和53年 9 月

5 ）加藤大介, 勝俣英雄, 青山博之：無開口後打ち耐震壁の耐 力の評価に関する研究，日本建築学会論文報告集，第 337 号, pp. 81-89, 昭和 59 年 3 月

6）益尾潔：鉄筋コンクリート耐震壁のせん断耐力に関する研 究, 日本建築学会構造系論文報告集, 第380号, pp. 76-87, 昭和 62 年 10 月

7）塩原等，細川洋治，中村哲也，青山博之：既存鉄筋コンク リート建築物の耐震補強工法に関する実験，第 6 回コンク リート工学年次大会論文集, pp. 405-408, 1984

8）大芳賀芳喜，長谷俊明，田中礼治：後打ち耐震壁補強に関 する実験的研究，(ホールインアンカーとケミカルアンカー の比較), 日本建築学会大会梗概集，構造，pp. 1647-1648， 昭和 56 年 9 月，既存鉄筋コンクリート建物の耐震補強に関 する研究，（その 3 コンクリート強度の弱い既存骨組の増 設壁補強実験), 日本建築学会大会梗概集, 構造, pp. 21532154 , 昭和 58 年 9 月

9）青山博之, 加藤大介, 勝俣英雄 : 増設 $\mathrm{RC}$ 耐震壁の耐力と 変形能の評価に関する実験的研究，(その 1 実験概要), (その 2 実験結果), 日本建築学会大会梗概集, 構造, pp.
1407-1410，昭和 57 年 10 月 同 日本建築学会，関東支部 研究報告集, pp. 169-176, 昭和 57年, 増設 $\mathrm{RC}$ 耐震壁の耐 力と変形能の評価に関する実験的研究，(その 3 開口の影 響および打継接合法の改良), 日本建築学会大会梗概集, 構 造, pp. 2151-2152, 昭和 58 年 9 月

10）野口博，丹羽亮，竹内正博，増田昭浩，丸太誠：増設 $R C$ 耐震壁の耐力と変形性能に与えるディテールの効果に関す る実験的研究，(第 1 報：実験概要），(第 2 報：実験結果の 検討), 日本建築学会大会梗概集, 構造, pp. 2147-2150, 昭 和 58 年 9 月

11）青山博之，細川洋治，塩原等，山本徹也：既存鉄筋コンク リート建物の耐震補強工法に関する研究，(その 1 鉄筋コ ンクリート後打ち耐震壁の実験)，(その 2 耐震壁内の応力 度の分布), 日本建築学会大会梗概集，構造，pp. 81-84, 昭 和 60 年 10 月

12）益尾潔，井上寿也，尾谷透，植松工：RC骨組の柱 CFRP 補 強と増設壁補強に関する補強，GBRC，No. 90, pp. 38-51， 1998.4

13）竹山博史，佐藤明敬，南伊三男，染谷俊章：プレキャスト 増設壁の施工と性能実験報告，プレストレストコンクリー ト, Vol.40, No.4, pp. 22-28, 1998.7

14）松田明，沢辺幸夫，山下博司： $\mathrm{RC}$ 造建物の耐震補強に関 する実験的研究, 日本建築学会大会梗概集, 構造, pp. 1691-1692，昭和 56 年 9 月

15）山村登志久，三須理右，近藤弘，立花正彦，中野清司：吹 き付けコンクリートによる RC 構造部材の耐震補強に関す る実験的研究，（その $1 \mathrm{RC}$ 増打壁および増設壁による耐震 補強)，日本建築学会大会梗概集，構造，pp. 589-590, 1997.9

（原稿受理年月日：1999年 9 月 10 日）

Strengthening Effects of Reinforced Concrete Infill Shear Walls

Constructed with Actual Specifications using Resin Type Anchors

By Kiyoshi Masuo, Toshikazu Sugimoto, Toshiaki Komiya and Mika Ohta

Concrete Research and Technology, Vol 11. No. 2, May 2000

Synopsis The anchors for the infill shear wall should be designed in consideration of the condition of construction site. In this study, the experiment was carried out to make clear the strengthening effects of the infill shear walls constructed with actual specifications using resin type anchors. In this experiment, the following parameters were considered. 1) The amount of anchors, 2) The compressive strength of concrete of the infill wall panel, 3) The sectional configuration of the boundary columns, 4) The additional shear walls with or without finish mortar. Also, the estimation method for the ultimate strength of the infill shear wall was investigated. The following conclusions were obtained. 1) The ultimate flexural strength of the infill shear wall is properly estimated in consideration of the effectiveness of the anchors. 2) In cases of a small amount of anchors and high compressive strength of the infill wall panel, its ultimate shear strength estimated by the guide line for the seismic retrofit in Japan is underestimated. 3) The ultimate shear strength estimated by the modified formulas good coincides with the tested value.

Keywords : Infill Shear Wall, Additional Shear Wall, Resin Type Anchors, Amount of Anchors, Compressive Strength of Infill Wall Panel, Ultimate Strength 